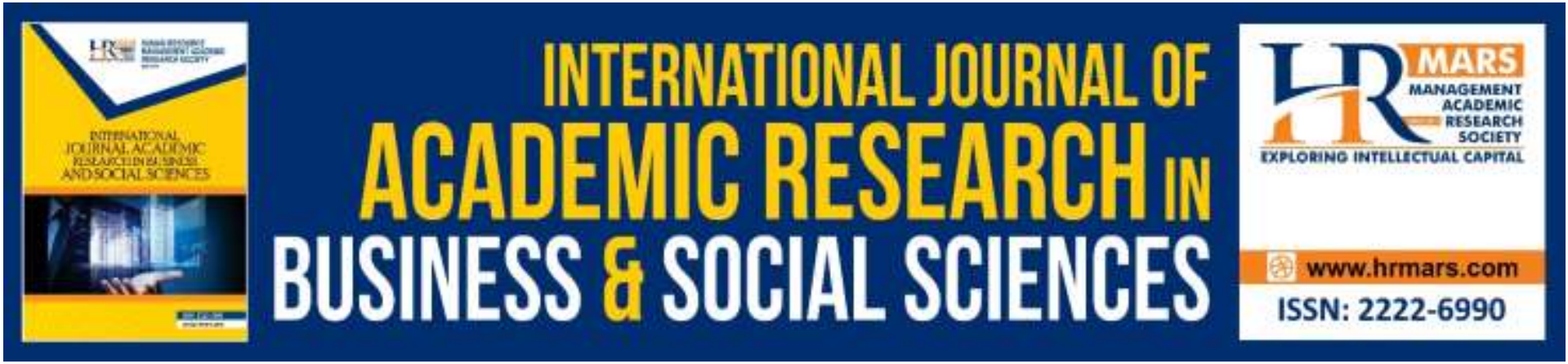

\title{
University Education and Employment Challenges: An Evaluation of Fresh Accounting Graduates in Malaysia
}

\author{
Lee Teck Heang, Ling Chui Ching, Lim Yet Mee, Cham Tat Huei
}

To Link this Article: http://dx.doi.org/10.6007/IJARBSS/v9-i9/6396

DOI: $10.6007 /$ IJARBSS/v9-i9/6396

Received: 16 July 2019, Revised: 11 August 2019, Accepted: 30 August 2019

Published Online: 25 September 2019

In-Text Citation: (Heang, Ching, Mee, \& Huei, 2019)

To Cite this Article: Heang, L. T., Ching, L. C., Mee, L. Y., \& Huei, C. T. (2019). University Education and Employment Challenges: An Evaluation of Fresh Accounting Graduates in Malaysia. International Journal of Academic Research in Business and Social Sciences, 9(9), 1061-1076.

\section{Copyright: (C) 2019 The Author(s)}

Published by Human Resource Management Academic Research Society (www.hrmars.com)

This article is published under the Creative Commons Attribution (CC BY 4.0) license. Anyone may reproduce, distribute, translate and create derivative works of this article (for both commercial and non-commercial purposes), subject to full attribution to the original publication and authors. The full terms of this license may be seen

at: http://creativecommons.org/licences/by/4.0/legalcode

Vol. 9, No. 9, 2019, Pg. 1061 - 1076

http://hrmars.com/index.php/pages/detail/IJARBSS

JOURNAL HOMEPAGE

Full Terms \& Conditions of access and use can be found at http://hrmars.com/index.php/pages/detail/publication-ethics 


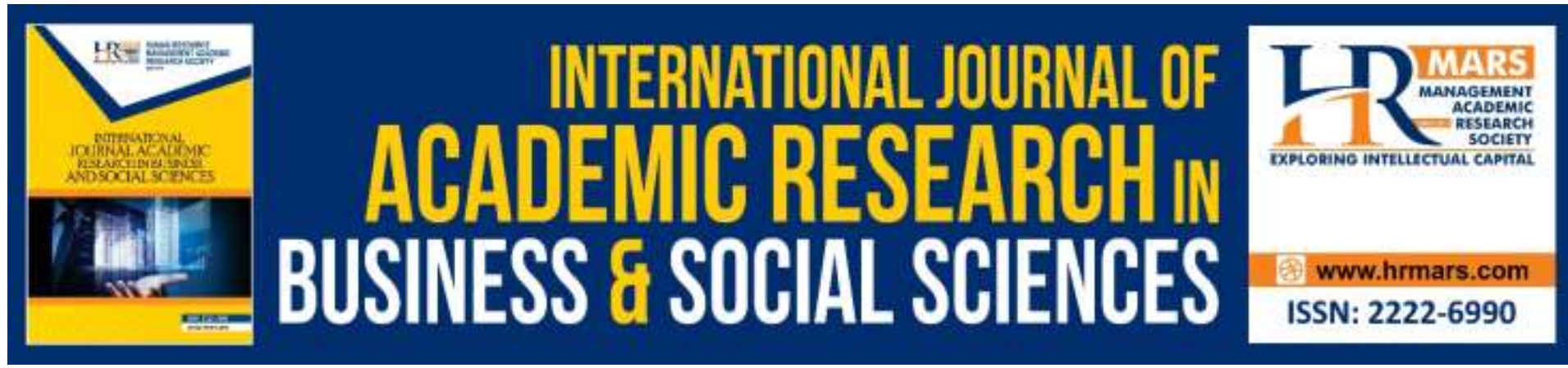

\title{
University Education and Employment Challenges: An Evaluation of Fresh Accounting Graduates in Malaysia
}

\author{
Lee Teck Heang \\ Faculty of Business, Economics and Accounting, HELP University, Malaysia \\ Ling Chui Ching \\ Faculty of Business, Design and Arts, Swinburne University of Technology Sarawak Campus, \\ Malaysia
}

Lim Yet Mee, Cham Tat Huei

Faculty of Accountancy and Management, Universiti Tunku Abdul Rahman, Malaysia

\begin{abstract}
Higher education and employment are two important life aspects for students as education is a stepping stone for them to enhance their future career opportunities. It is crucial to examine how they perceive the performance of their university in preparing them for the job market, as well as the early employment problems encountered by them. Semi-structured telephone interviews were conducted to get inputs from 18 fresh accounting graduates. The study found that the fresh accounting graduates encountered various problems while at work. These early employment problems include: (i) insufficient technical knowledge, (ii) poor communication skills, (iii) not tech-savvy, (iv) difficulty in adapting to workplace, (v) inadequate stress and time management skills, and (vi) a lack of hands-on experience. The study also indicated that many of the interviewees are less satisfied with the performance of their respective universities. The accounting graduates expect their courses to emphasize more on the practicality instead of the theoretical aspects. It is suggested training could be provided to the newly hired accounting graduates to reduce their early employment problems. On the other hand, university should make internship compulsory for accounting students to provide them with real work life experience before they are hired. The findings of this study provide an insight to the education providers to enable them to develop more effective accounting curriculum to produce better-equipped graduates for the job market.

Keywords: Accounting Education, Early Employment Problems, Soft Skills, Internship, Malaysia.
\end{abstract}




\section{Introduction}

A university is a higher learning institution where knowledge and skills are imparted to the students. However, expectations on university's education have evolved and expanded. The role of the university is no longer limited to imparting knowledge and skills but also to ensure that students will be able to secure decent employment after their graduation. Universities are expected to produce students who are job-ready with skills that they are able to use and apply to their jobs. West (2000) claims that higher education and employment are closely related as individuals hope to enhance their future careers opportunities through higher learning.

A recent survey conducted by Ipsos Market and Opinion Research International (MORI cited in Falcone, 2016, p. 57) in March and April of 2015 where 5,550 parents from 16 countries participated in the study. The results indicate that 79 percent of the parents find an undergraduate degree important as it enables their children to achieve their personal and ultimate goals in their lives. The survey also revealed that 83 percent of the parents wish their children to have a career in a specific type of employment. For example, 19 percent of the parents expect their children to secure a job in the medical industry, 11 percent in engineering, and 8 percent in computer science. The results of the study indicate that there is a clear linkage between education and subsequent employment.

Despite a high expectation on tertiary education in producing quality graduates to meet the need of the labor market, a "graduate skills gap" still exists when comes to fulfilling the demands of the labor market (Aziz, 2018). A study was conducted by the Institute of Student Employers in 2018 to examine the relationship between graduate skills and employer expectations in today's dynamic business environment. This study surveyed the opinions of 11,000 employers and 16,000 students across the world. The results of the study show that there are "sizable and consistent disparities" between employers' expectation and actual skills that the students possessed (Aziz, 2018; The Global Skill Gap in the 21 Century). This implies that curriculum provided by the universities may not have successfully equipped their graduates with the "employability skills" needed by the employers in the industry.

It is also found that today's employers are reluctant to provide training to their employees unlike those employers of the past (Kasriel, 2018). Present employers expect university graduates to be able to perform in their jobs once they are hired. However, a survey conducted by Monster India with over 5,000 job seekers and employers found that 66 percent of the fresh graduates are not ready for the job market (Pant, 2018). Once again, this implies that formal education provided by universities may not have prepared their students for the working world. In addition, another study conducted by Monster.com in Malaysia revealed that over one third of the Malaysian fresh graduates quit their first job in less than a year (Azahar, 2017). One of the major obstacles faced by them was lacking industry knowledge. The study suggested that courses offered by the universities could be overly emphasized on theories, with insufficient industry collaboration or internships for the students to gain handson experience.

A qualitative study is needed to gain a better understanding on the current situation highlighted above. Interviews were conducted to obtain feedback from the fresh accounting 
graduates who have just secured their first jobs. The objectives of the present study are to (i) identify problems in connection with their early employment, and (ii) examine how well the universities have prepared them for the workplace. The findings of the present study will make a contribution to the literature as very few studies have been conducted to examine such research issues in Malaysia. The findings of the study can also be used as a basis to develop a more effective accounting curriculum to produce better-equipped graduates for the job market.

\section{Literature Review}

\section{Accounting Education and Employability Skills}

Obtaining a university degree in Accountancy is one of the pathways leading to a career in the accounting and finance industry. The knowledge gained through such a formal education should prepare the students to be technically competent with the required professional skills. Accounting graduates should gain both technical and generic or soft skills through tertiary accounting education. According to International Education Standard 2 (IES2) issued by the International Accounting Education Standards Board, technical competence must be achieved by the accounting students at the end of a professional accounting education program. IES2 covers the technical competencies in using professional knowledge to accomplish a particular duty within the defined standards. Generally, accounting graduates are expected to be technically competent in the following areas:
(a) Financial Accounting and Reporting
(b) Management Accounting
(c) Finance and Financial Management
(d) Taxation
(e) Audit and Assurance
(f) Governance, Risk Management and Internal Control
(g) Business Law and Regulations
(h) Business and organizational environment
(i) Economics
(j) Business strategy and management.

The professional skills of the accounting students are also emphasized by International Education Standard 3 (IES3). The skillsets include the following:
(a) intellectual
(b) interpersonal and communication,
(c) personal,
(d) organizational

Examples are given in IES3 to further illustrate each of the professional skillsets. One of the examples used to describe intellectual skills is the ability to assess information from different sources and perspectives via research, analysis, and integration of information. Intellectual skills refer to the ability to arrive at a conclusion based on professional judgement upon all available facts and information. In addition, accounting graduates are expected to possess interpersonal and communication skills where they are able to work in a team in achieving 
the organizational goals. They should also be able to communicate clearly and precisely in professional discussion and presentation. In terms of personal skills, one should be committed to lifelong learning. Accounting graduates should have the ability to apply professional skepticism when necessary to question the credibility and reliability of the information received. Lastly, they are also expected to exercise organizational and leadership skills to influence another person to work towards the organizational goals.

Even though the learning outcomes of the accounting degree programs offered by all universities across countries have to be somehow in line with the requirements of the International Accounting Education Standards Board, it is important to identify the specific skills needed by the employers from the industry. Accounting graduates equipped with such skills are generally more employable. Hence, these skills are regarded as "employability skills". Various studies have been conducted to identify the employability skills from the perspectives of different parties. Survey studies have been done (e.g., Lim, Lee, Yap and Ling, 2016) to examine perceptions on the employability skills of accounting graduates from various parties. Employers of accounting firms, junior employees, accounting lecturers, and accounting students have been included in these studies. Generally, the studies found that accounting graduates do not possess the required employability skills desired by the employers. Examples of desirable skills include IT skills (able to use Microsoft Excel and Words), analytical skills, ability to work in a team, organizational skills, problem solving skills, business awareness, 'real life' experience, basic accounting skills, ethics professionalism, fraud awareness, communication skills, ability to work in teams, ability to defend views (communication, presentation and speaking skills), positive attitudes (committed, passionate, dynamic, energetic, vibrant, and self-driven), using information technology, application of leadership skills, meeting datelines, understanding group dynamics, be observant and aware, ability to act and think strategically, ability to analyze conceptualize issues, and be adaptive (Dean and Campbell, 2010; Kavanagh and Drennan, 2008; Tan and Laswad, 2018).

\section{Early Employment Problems}

Getting a job is the next step for most of the fresh graduates after obtaining a degree. It is not surprising that they will encounter various challenges in the workplace as this could be the first time they are exposed to a working environment. Gericke (2017) found that fresh graduates may not have prepared themselves well for work. The time students spent in universities does not by itself means that they are ready to meet the demands in their jobs. In particular, the author pointed out that fresh graduates may not be able to work in a team and handle different people with different characters in the workplace. Striking a balance between work demand and personal life and handling their financial issues are also some of the challenges faced by the fresh graduates.

Pradana and Salehudin (2015) conducted a survey in Indonesia to examine how workload affects the turnover intention of the newly hired junior auditors. Junior auditors with working experience of six months to two years participated in the study. Their study found that workload has a significant negative effect on job satisfaction and a significant positive effect on work-related stress and work-life conflict. The study also indicated that work-related stress significantly increases employee turnover intention. Such findings are consistent with the explanation given by Lee, Lim, Yap and Tam (2011) who argued that auditors are subject to a 
high level of stress as they are often required to complete their tasks within a short period of time while maintaining the quality of their work. The amount of stress could be unbearable for fresh graduates who are unaccustomed to the challenging workplace. As a result of the intense workload during the audit peak period, undue level of stress can be put onto the fresh graduates resulting in a high turnover rate among these entry-level employees.

The study by Lee, Lim, Yap and Ling (2013) revealed the issues and challenges of hiring audit juniors in Malaysia. The study found that many newly hired accounting graduates are not jobready despite having excellent academic performance. They are falling short of proper command of both oral and written language skills in English. To overcome this problem, many firms have to provide English classes to the new recruits on a regular basis to sharpen their language skills. In addition, the audit partners found many audit juniors are deficient in their technical knowledge. Very often the new recruits discover that what they have studied in the university is only such a small part of the technical knowledge needed in their jobs. Many of the new audit recruits are reluctant to take the initiative to probe and analyze the figures during the auditing process even though professional skepticism is strongly emphasized in the auditing process. The study also found that many new audit recruits lack "EQ" (emotional intelligence), an important requisite in a client-servicing industry. Many of the audit juniors do not communicate and interact well with their audit clients. They lack of certain leadership quality and are incapable of conducting a meeting effectively with the clients. Furthermore, many of them lack the ability to work in teams as they are neither good team players nor good listeners.

The findings of Lee et al (2013) are further supported by the study of Lim, Lee, Yap and Ling (2016) where the authors conducted a survey to examine the early employment problems of junior auditors in Malaysia from the perspectives of employers and junior auditors. The top five early employment problems perceived by the employers are: (i) lack of technical knowledge, (ii) difficulty in applying knowledge to practice, (iii) lack of communication skills in English, (iv) difficulty in adapting to workplace, and (v) poor attitude. On the other hand, junior auditors perceived the following as early employment problems: (i) difficulty in adapting to workplace, (ii) lack of technical knowledge, (iii) time management, (iv) difficulty in handling stress, and ( $v$ ) lack of experience.

Courtis and Zaid (2002) asserted that most of the early employment problems can be resulted from an "expectation gap" between the graduate employees and employers. The employers often expect the graduate employees to be able to handle the tasks assigned to them in a diligent and competent manner. However, due to a lack of practical experience, the graduate employees may not be able to live up to the employers' expectation as the knowledge gained from formal education is mainly on theoretical grounds. The major early employment problems identified in their study are as follows: (i) application of theoretical studies, (ii) report writing, (iii) communication with others, (iv) comprehension of responsibilities, and (v) working in a team. Efforts should be taken to identify solutions to help the accounting graduates to overcome the early employment problems. Such problems "can lead to a reduction in productivity, diminished professional identity, absenteeism, increased level of staff turnover, and a truncated career in accounting" (Courties and \&Zaid, 2002, p. 320). 


\section{The Role of University in Preparing Students for the Workplace}

How well universities have prepared the accounting students to fit into the actual workplace is an important question to raise. Citing data from Global Limelight Work Readiness Survey, Chiew (2018) reported that, prior to securing a job, 73 percent of the employees who participated in the survey were of the opinion that they were equipped with the necessary skills and capabilities needed to perform in the workplace. However, their level of confidence dropped when they actually performed their jobs. Only 39 percent of the employees reported that they were less than prepared or not prepared at all for their first job. In addition, they found the skills and knowledge learned from the university courses are not keeping abreast with the latest industry practices.

Mastracchio (2017) asserted that formal accounting education provided by the universities are often criticized for being "bloated, inefficient, obsessed with research, and inadequate in preparing students for the workforce". This remark, to a large extent, could be valid as universities have put in tremendous effort and resources in producing a large quantity of research and publications in order to improve their ranking in the academic industry. Both the Times Higher Education World University Ranking and QS World University Ranking have emphasized highly on research work. For example, the performance indicators of Times Higher Education World University Ranking are grouped into five areas: (i) Teaching (30\%), (ii) Research (30\%), (iii) Citation (30\%), (iv) International Outlook (7.5\%), and (v) Industry Income (2.5\%). On the other hand, the performance indicators of QS University Ranking are: (i) Academic Reputation (40\%), (ii) Employer Reputation (10\%), (iii) Faculty/Student Ratio (20\%), (iv) Citation Per Faculty (20\%), (v) International Faculty Ratio/International Student Ratio (5\% each). Based on the performance indicators, it can be seen that the bases to evaluate the university's performance are not very much on how well the university is producing graduates to meet the employers' needs. Hence, it could be surmised that universities may not be very keen on pleasing the employers.

The above shown some of the shortcomings of universities in producing well-equipped and job-ready graduates for the current employment market. However, there is a need to conduct more up-to-date and in-depth academic studies to gain a comprehensive understanding on issues pertaining to this area. Information obtain from such research studies would provide a good insight on the quality of accounting education in Malaysia. It can also be used as a basis to improve the current accounting curriculum to align with the expectation of the employers in the present job market.

\section{Research Methodology}

A qualitative method of semi-structured telephone interview was used for the purpose of this study. A qualitative approach allows an in-depth investigation to be conducted on the research issues. A comprehensive insight can be obtained through personal interviews where opportunities are given to the participants to express freely on their views and past experiences with regard to the questions raised by the researchers. This approach enables the researchers to obtain reliable and profound insights as well as the richness of the research data.

The selection criteria for the interviewees were: (i) obtained an accounting degree from a Malaysia university not more than three years ago, (ii) currently working in accounting related 
job in Malaysia (e.g., financial accounting, management accounting, taxation, internal and external audit, finance, and banking), and (iii) total working experience not more than three years. Eighteen interviewees who met the selection criteria were approached and participated in the research study. To improve the quality and reliability of the study, the diversity of the participants was ensured in terms of their ethnicity, working experience as well as the university from which they obtained their accounting qualifications.

The number of participants in this study is believed to be sufficient as the current study promotes the quality of the information elicited from the interviewees instead of the number of interviews to be conducted. The purposive sampling method with the stringent selection criteria ensures the appropriateness of the interview candidates. A total of 21 questions were raised in the telephone interviews. The first six (6) questions were used to obtain the profile of the interviewees. It is followed by eight (8) questions asking about the interviewees' working experiences as well as their workplace. The purpose of these eight questions was to obtain an understanding of the early employment problems of the accounting graduates. To identify how well the universities have prepared the accounting graduates in their workplace, seven (7) questions were posed to the interviewees. The duration of each telephone interview ranged from 20 to 30 minutes and were recorded for further analysis. All recordings were subsequently transcribed in text, and thematic analysis was used to analyze the data. Thematic analysis is appropriate for the purpose of the present study as it identifies the themes and patterns from the qualitative information obtained from the interviews (Maguire \& Delahunt, 2017). This helps to synthesize the qualitative data and present the results of the study in a clear and easy-to-follow manner.

\section{Results}

\section{Issues on Early Employment Problems}

Though the main aim of accounting education is to equip students for workplaces (Zraa, Kavanagh, \& Hartle 2011), it is not uncommon that fresh accounting graduates will still face employment problems when they are newly hired (Lim, Lee, Yap and Ling 2016). To determine the issues that fresh accounting graduates often encounter in their workforce, interviewees were asked three (3) related questions. They were required to describe the problems that are often encountered when they are newly hired, explain how they manage to overcome these problems, and whether these problems were raised to their employers.

One of the common early employment problems that pointed out by 18 interviewees is difficulty in adapting to their workplace. For example, one of the fresh graduates who just joined the auditing firm said that she went through a struggling period to learn the audit software and be familiarized with the auditing procedures in order to carry out her daily work. Another interviewee highlighted that even she worked hard to get used to the workplace, she still could not keep up with the pace required by her senior. Apart from the need to understand the business nature and model of their company, newly hired employees in the accounting related jobs have to learn certain accounting software. Most of them commented that they have to unlearn and relearn new accounting software which is different from what they have learned in the university. 
Another early employment problem experienced by six (6) of the interviewees is difficulty in handling stress. The stress is mainly due to long working hours and heavy workload. Some respondents working in the auditing firms mentioned that they were expected to stay back after office hours if their seniors or managers had not yet left the workplace, even though they had completed their tasks for the day. They indicated that they often feel stressful and are not able to achieve work life balance working in the audit line. On the other hand, one of the respondents who was hired by an event management company expressed her concern of being overloaded with work. She needed to deal with a huge backlog of work in addition to the existing tasks at hand. She complained that she was not given enough time to finish the work assigned to her. Besides these two aforementioned early employment problems, other problems raised by the participants include a lack of technical knowledge on accounting standards and taxation and inadequate practical or internship experience and exposure.

More than half of the participants indicated that they overcame their early employment problems by seeking help from their seniors, colleagues, managers or employers. Nevertheless, four (4) of the respondents reported unpleasant experiences whereby their seniors or colleagues were reluctant to provide guidance especially when they were occupied with their own work. In other words, this is the problem of inadequate support given by the seniors or superiors. Nine (9) of the interviewees resolved to figure out the solution of work problems themselves by getting assistance from other people and attending training and seminars. They also referred to other relevant documents such as previous work files and online resources to equip themselves with technical knowledge. Another respondent even raised the issue of the supervision given by her senior which was different from the requirement of the employer. In other words, she encountered the problem of role conflict at work.

Fifteen (15) participants reported that they were reluctant to raise problems to their employers. They preferred to discuss the issues with their seniors or team members. Normally the seniors were able to clarify their doubts, take action to help them or take note of the highlighted issues. One of the participants recalled that her immediate superior refused to help her once so she ended up raising her concerns to the management directly. Another participant did not see the need of bringing up the issue to the management as he perceived that this is his own personal problem.

A question was posed to the respondents to gauge the technical and soft skills that they deemed to be lacking while performing their jobs. Six (6) respondents believed that their communication skills were inadequate. One of the respondents struggled at one point in time when presenting her financial reports to her colleagues from various departments and different levels of organization. She was struggling not to use accounting jargons so that her colleagues with non-accounting background could understand her presentation. A few participants also highlighted the problem of language barriers when attempting to communicate with their counterparts using English language, especially with those from the foreign companies. Some interviewees stressed that the mastery of communication skills would boost their level of confidence and networking skills. Other soft skills that the respondents considered lacking were time and stress management skills. Often, they are 
required to multitask on projects with different deadlines and stages of completion, thus they felt that they were working under pressure with tight schedules.

Six (6) of the interviewees stated that they lacked of information technology skills. They needed to learn accounting, taxation, auditing or spreadsheet software in order to be able to perform in their jobs after they joined the workforce. They felt that the university did not equip them well with the information technology skills. Some participants also considered themselves to be inadequate in the accounting skills. They are concerned with the lack of knowledge on accounting standards and the ability to interpret and apply the accounting standards when preparing the financial reports. Furthermore, one (1) respondent wished to improve her data analytical skills so that she has the ability to interpret financial data and execute in-depth financial analysis.

When the interviewees were asked about the expectation gap (the difference between the employees can offer as compared to the requirements of the employers) in relation to knowledge, skills, and working attitude, majority of them believed that expectation gap did exist. These respondents revealed that their employers expected them to be able to handle the tasks assigned to them diligently, competently, and independently within a short time frame. One interviewee even used the term "perfectly" to describe the high expectation that her employer had towards her. The employers expected the entry-level employees to be knowledgeable on accounting standards, be willing to work long hours, and to possess skills in time and stress management as well as in information technology. On the other hand, the employees expected their employers to be helpful, to treat the employees politely, and to guide the employees to exercise critical thinking in evaluating and analyzing financial reports.

Participants were asked how their company helped them formally to cope with their job functions. Most of the interviewees mentioned that their companies provided in-house training on technical knowledge, information technology skills, and soft skills. Some companies provided e-learning so that the employees could study online at their own pace. Occasionally, the companies also sent the employees to attend training programs organized by the Malaysian Institute of Accountants (MIA) or by other accounting professional bodies. Five (5) respondents reported that they received assistance from their seniors in the form of on-the-job training. Their seniors coached them on how to use software, brought them to client's office, set learning goals for them to achieve, and to provide them with handbooks and manuals for references.

This section highlighted the various problems encountered by the fresh accounting graduates in their workplace. As novices in the company, the problems that they have encountered can be taken as a learning experience. This can be seen as a good opportunity for them to improve their technical and soft skills. Hence, the fresh graduates should take these challenges positively. On the other hand, employers should be more considerate and tolerant with these novices as this is a natural process for them to acquire the required skills through real-life experience at the workplace. 


\section{Performance of the University in Preparing Students for the Workplace}

One of the major roles of universities in the present-day environment is to prepare their students to fit-in well into the society. Hence, students who have graduated from a university should be job-ready, confident and well equipped with all employability skills needed to perform in the workplace. To assess how well universities have prepared their graduates with such criteria, three (3) related questions were posed to the interviewees. They were required to rate in the scale of 1 (lowest) to 5 (highest) whether they are job-ready, their level of confidence and whether their universities have equipped them with the necessary soft and technical skills for the workplace.

Nine (9) out of 18 of the interviewees rated themselves not more than 3 in terms of their job readiness when they were asked if they were prepared to work in an organization. They indicated that they were not job-ready because of the actual work environment. Whatever they learned from the university were found to be different from the real-life situation. They feared that the skills acquired in the university might not be compatible with what was expected from their employers. They believed that they failed to possess sufficient practical skills to enable them to perform well in their workplace. One of the interviewees pointed out that she began to realize that she was not ready for the job right after attending the interview, when she was told what was expected from her in her job scope. Of those rated more than 3 generally find themselves to be job ready. Many of them found that the internship experience arranged by the university gave them a chance to expose themselves to the real business world. They did not find themselves alien to the workplace when they were offered a permanent position in the company.

The study found that 14 of the interviewees do not rate their confidence level more than 3 when it comes to performing their job when they are newly hired. Many of them argued that they are not confident because they do not have any working experience prior to accepting the current employment offer. Hence, they are doubtful if they are able to live up to the expectation of the employers. However, some of the interviewees asserted that the experiences working at part-time jobs helped in boosting up their confidence level. This is despite the nature of the job could be completely different. One of the interviewees stressed that whatever learnt in the university will only serve as a guide and it may not be totally applicable in the workplace. Some of the interviewees realized that there is a time frame needed to get used to the working environment and this is part of the natural learning process.

A question was posed to the interviewees if they acquired relevant technical and soft skills from the university. Fourteen (14) of the interviewees did not seem to be satisfied with what they have learned in school. They gave a rating of 3 and below when asked whether they acquired sufficient technical and soft skills from their university. Some interviewees commented that they are not given sufficient chances to do presentations in class. They pointed out that throughout the 3-year course, they were only required to do presentation not more than 3 times. Some of the interviewees commented that it was very common that lecturers did the talking and students were only required to listen. There was not much mutual interaction in the class. They stressed that conventional teaching methods were no longer effective whereby lecturers and students kept a distance from each other as part of 
the Asian culture. The use of mother tongue (Chinese, Malay or Tamil language) was common among peers in the university and English was used only when they needed to communicate with the lecturers. Some of the interviewees were not satisfied with the IT skills acquired from the university. For example, one of the interviewees said that MYOB was taught in the class but it was not commonly used in the industry anymore. As a result, she had to learn other accounting packages on the job. In addition, the use of Excel was too superficial in the class when compared to its use at the workplace. (Ahmed, Umrani, Qureshi, \& Samad, 2018; Ahmed, Isa, Majid, Zin, \& Amin, 2017).

In contrast, 4 interviewees think that they have acquired sufficient technical and soft skills from their university by providing a scale of 4 over 5 . They commented that their university did a good job by providing them with the chance to acquire some of the soft skills. For example, they are required to do class presentations as part of the coursework assessments and this gives them the courage to speak in front of an audience. They argued that such training has enabled them to have the ability to maintain a decent conversation with colleagues and clients. It also helps them to have the guts to bring up ideas to their employers. One of the interviewees mentioned that her university only allows English to be used in the campus and this has given the students a golden opportunity to sharpen their English language proficiency. They opined that taking part in social activities and competition did help them to acquire some of the soft skills such as communication skills, leadership skills as well as time and stress management skills

Interviewees were asked to provide some suggestions to the university to help students to improve their employability. Some interviewees suggested that university accounting curriculum must be "practical' and in line with the current development of the industry. This would help students to obtain relevant, timely and up-to-date information to live up to the expectation of the employers. They also suggested the university to move away from the heavily examination-based assessment method to a more flexible and practical one. They argued that it would help to promote 'critical thinking,' instead of churning out tons of book worms. In addition, many of them emphasized that internship is very important for the accounting graduates as it gives them the opportunities to gain some practical experiences prior to joining the industry permanently. They commented that even though the tasks given to them during the internship period could be trivial but it still provides them a chance to be familiarized with the actual working environment. One of the interviewees suggested that the university should collaborate with the international accounting firm to organize audit simulation activities to provide real audit experience for the students. In addition, most of them found that the final-year research project, which requires them to prepare a dissertation, did not help them with their jobs. They opined that such research project is only relevant for those who intend to pursue a master or PhD degree leading them to an academic career.

The final question posed to the interviewees is whether they have an intention to enhance their skills through further education. 17 out of 18 of the interviewees are either currently pursuing or have intention to pursue further education. Their choices of further education are mainly on professional courses such as ACCA, ICAEW and CPA Australia. They believe that the undergraduate degree has only provided them the fundamental basic knowledge and further education is needed in to order for them to advance in their career. They understand that to 
be a professionally qualified accountant or auditor in Malaysia, professional qualification cannot be avoided. The only interviewee who did not have an intention to pursue her further qualification has given the reason that she is married with a child. Hence, she does not have the luxury of time to pursue higher qualification as she has to spend quality time with her family.

Overall, most of the interviewees are less satisfied with what they have acquired from the university. Most of them are also not job-ready as they are lacking of confidence at work. Interviewees expect the accounting curriculum to be more practical and hands-on. Many of the interviewees emphasized that internship is very important for the accounting graduates as it gives them the opportunities to gain some practical experiences prior to joining the industry permanently. In addition, almost all of the interviewees intended to pursue their further studies and this is likely to suggest that an accounting degree qualification offered by the universities can no longer satisfy the needs of the present employers. As a result, many of them opted to study professional accounting qualification to enhance their skills, knowledge as well as paper qualification for their career advancement.

\section{Discussion and Conclusion}

Through 18 semi-structured telephone interviews, the study uncovered the early employment problems encountered by the fresh accounting graduates and how well they perceived their universities have prepared them for the job market. The results showed that the most common problems experienced by them during the early stage of their employment are insufficient technical knowledge, poor communication skills, not tech-savvy, difficulty in adapting to workplace, inadequate stress and time management skills as well as lack of experience and exposure from practicum or internship.

Employers may have to consider undertaking extra responsibility of providing training (with soft skills as the focus) to their newly hired accounting graduates, as suggested by Low, Samkin and Liu (2013). These additional efforts may help to (1) reduce early employment problems, (2) enhance job satisfaction and job performance, and (3) decrease employee turnover intention, and (4) reduce expectation gap between the employers and employees (Courties \& Zaid, 2002; Pradana \& Salehudin 2015; Ahmed, Majid, \& Zin, (2016). The closing of expectation gap implies the fulfillment of employers' expectation and requirements. On the other hand, the reduction of early employment problems would lead to higher job satisfaction and job performance among the entry-level employees, this in turn, would result in lower turnover intention.

The research findings also indicate that fresh accounting graduates are less satisfied with the performance of their respective universities. They are not well-prepared and ready for the working world despite possessing an undergraduate degree. It is believed that the accounting curriculums overly emphasize on the theoretical aspects rather than the practical. In addition, accounting course syllabus should be more industrial-oriented with more hands-on and reallife learning. They believe that the incorporation of such components in the curriculum design of the accounting education will enable accounting graduates to be more employable in the job market. The importance of internship cannot be undermined as it gives the accounting students a real-life experience in the actual workplace before they are selected and hired. According to Zhang Zhiqing, the Vice-Dean of the Chongqing University-University of 
Cincinnati Joint Co-op Institute, "there is a gap between college education and the skill sets needed by the market" and "the internship narrows the gap by pushing them to face realworld problems and even have a chance to experience the cutting-edge trends of the industry (as cited by Yuan, 2017)"

Despite its practical contributions, the present study has the following limitations. Firstly, the research findings are only based on 18 interviews conducted with the fresh accounting graduates as the target respondents. The reliability of the findings can be enhanced with a larger sample size. The quality of the findings from the interviews can also be enhanced if a mixed approach is used. In addition to interviews, a survey can be carried out to investigate the perception of the larger group of fresh accounting graduates with a wider geographical coverage. Data were collected only from one key stakeholder group--the accounting graduates. The findings could be more comprehensive if the opinions from other key stakeholder groups such as the employers and the education providers are included. A meaningful comparison can then be made with richer insights from various perspectives. It would also be interesting if a cross-country study is conducted to identify the similarities and differences of early employment problems of the entry-level employees in accounting-related jobs. The performance of different universities in different countries in preparing graduates for the job market can also be examined.

In conclusion, the university plays a critical role in preparing our accounting graduates for the job market. The performance of the university may be the root for all these issues of concern-student employability, expectation gap, early employment problems, job satisfaction, job performance, and turnover rate in the industry. The university may have to relook and redesign the accounting curriculum to make it more practical-oriented. This requires collaboration from various parties-university, professional bodies, academics, and the existing employees in the accounting-related field. Among all these parties, the entry-level employees would be the most relevant group in providing insights for the research studies on employability issues.

This study contributes towards the understanding of the challenges faced by fresh accounting graduates in meeting the demand of employers and how well the universities have equipped them for the workplace. The findings of this study can be used as the basis to revise the current content of the accounting courses which in turn enable them to be more in line with the requirements needed for the present job market. On the other hand, based on the information obtained from this study, universities and accounting professional bodies can provide free accounting seminars to the fresh graduates to further enhance their employability skills. In additional, the latest update of the accounting development can also be given to them through these free courses. By doing so it will help to improve the quality of the accounting graduates,

Acknowledgement: The authors would like to acknowledge the grant provided by HELP University to fund this research project and thank Puah Ting Wei for his help in data collection. 


\section{References}

Ahmed, U., Isa, N. M., Majid, A. H. A., Zin, M. L. M., \& Amin, B. M. (2017). Towards understanding work engagement: can HR really buffer HR? Test of a moderated model. International Journal of Economic Research, 14(20), 1-18.

Ahmed, U., Majid, A. H. A., \& Zin, M. L. M. (2016). HR Moderating HR: Critical link between Developmental HR Practices and work engagement in a Moderated Model. Management Review: An International Journal, 11(2), 4-22.

Ahmed, U., Umrani, W. A., Qureshi, M. A., \& Samad, A. (2018). Examining the links between teachers support, academic efficacy, academic resilience, and student engagement in Bahrain. International Journal of Advanced and Applied Sciences, 5(9), 39-46.

Azahar, W. (2017). Over a third of Malaysian fresh graduates quit first job in less than a year. Human Resources.

Aziz, H. (2018). Graduate skills gap. News Strait Time. Retrieved from

Chiew, S. (2018). Do universities prepare students enough for their first jobs? The Edge Singapore.

Courtis, J. K., \& Zaid, O. A. (2002). Early employment problems of Australian accounting graduates: An exploratory study. Accounting Forum, 26(3), 320339.

Dean, P.C. \& Campbell, J. (2010). What do companies expect of accounting major? Review of Higher Education and Self-Learning, 3(7), 101-106.

Falcone, S. (2016). Linking Education and Employment: Certificate Programs at US Institutions 1980 - 2013. Journal of Higher Education Theory and Practice, 16(3) 2016, 57-73.

Gericke, S. (2017), Now what? Problems graduates encounter in the workplace. University Pretoria News. Retrieved from

http://ojs.aishe.org/index.php/aishe-j/article/viewFile/335/553 [Assessed 3 February 2019]

International Education Standard (IES) 2, Initial Professional Development - Technical Competence (Revised), International Accounting Education Standards Board.

International Education Standard (IES) 3, Initial Professional Development - Professional Skills (Revised), International Accounting Education Standards Board.

Kasriel, S. (2018). Young Workers No Longer Get the On-the-Job Training They Need -- So They're Finding It Elsewhere. Entrepreneur Asia Pacific. Retrieved from https://www.entrepreneur.com/article/314468 [Assessed 29 January 2019]

Kavanagh, M. H., \& Drennan, L. (2008). What skills and attributes does an accounting graduate need? Evidence from student perceptions and employer expectations. Accounting \& Finance, 48(2), 279-300.

Lee, T. H., Yap, C. S., \& Yap, Tam, C. L. (2011). Stress at Work Amongst Auditors: Is There a Light at the End of the Tunnel? MAREF Review, 1(2), 1-3.

Lee, T.H., Lim, Y.M., Yap. C.S. \& Ling, C. C. (2013). Audit Juniors in Malaysia: Issues and Challenges. Maref Review, 4 (2), 10-12.

Lim, Y. M., Lee, T. H., Yap, C.S. \& Ling, C. C. (2016). Employability skills, personal qualities, and early employment problems of entry-level auditors: perspectives from employers, lecturers, auditors, and students. Journal of Education for Business, 91(4), 185 - 192.

Low, M., Samkin, G. \& Liu, C. (2013). Accounting education and the provision of soft skills: implications of the recent NZICA CA Academic requirement changes. e-Journal of Business Education \& Scholarship of Teaching, 7(1), 1-33. 
Maguire, M. \& Delahunt, B. (2017), Doing a Thematic Analysis: A Practical, Step-by-Step Guide for Learning and Teaching Scholars, AISHE-J, 8 (3), 3,3511- 33514. Retrieved from

Mastracchio, N. J. (2017). A Positive Look at Accounting Education. CPA Journal. Retrieved from https://www.cpajournal.com/2017/09/21/positive-look-accounting-education/ [Assessed 14 January 2019]

Pant, D. (2018). 66\% of the fresh graduates think they are not job ready: Survey. People matters. Retrieved from

Pradana, A., \& Salehudin, I. (2015). Work overload and turnover intention of juniors in greater Jakarta, Indonesia. The South East Asian Journal of Management, 9(2), 108-124.

Setyaningrum, D., Muktiyanto, A. \& Hermawan, A.A. (2015). How Indonesian Accounting Education Providers Meet the Demand of the Industry. International Research Journal of Business Studies, 8(1), 1-11.

Tan, L. M., \& Laswad, F. (2018). Professional skils required of accountants: What do Australian and New Zealand job advertisements tell us? Accounting Education. 27(4), 403-432.

The Global Skill Gap in the 21 Century. Retrieved from http://info.qs.com/rs/335-VIN535/images/The\%20Global\%20Skills\%20Gap\%2021st\%20Century.pdf. [Assessed 20 January 2019]

West, J. (2000). Higher education and employment: opportunities and limitations in the formation of skills in a mass higher education system, Journal of Vocational Education and Training, 52:4, 573-588.

Yuan, S. (2017), Bringing together classroom learning, real-world applications. China daily.

Zraa, W., Kavanagh, M. \& Hartle, T. (2011). Teaching accounting in the new millennium. Proceedings of the Cambridge Business and Economics Conference. USQ ePrints. Retrieved from 